\title{
NELIDA (BONEKA LIMBAH CERDAS) SEBAGAI SARANA EDUKASI PENDIDIKAN SEKSUAL DALAM UPAYA MENCEGAH KEKERASAN DAN PENYIMPANGAN SEKSUAL PADA ANAK DI SD MUHAMMADIYAH 9 SURABAYA
}

\author{
Erica Ayu Damayanti ${ }^{1}$, Marta Kusuma Putri ${ }^{2}$, Judith Syifa Fauziah Maria Rahman ${ }^{3}$, \\ Fatma Aula Nursyifa ${ }^{4}$, Gita Marini ${ }^{5}$ \\ Fakultas Ilmu Kesehatan Universitas Muhammadiyah Surabaya \\ J1.Sutorejo 59 Surabaya \\ E-mail: gita.ners82@gmail.com
}

\begin{abstract}
ABSTRAK
Penyimpangan dan kekerasan seksual terhadap anak-anak adalah fenomena yang sering terjadi saat ini. Salah satu faktor yang mempengaruhi kasus penyimpangan dan kekerasan seksual pada anak-anak karena rendahnya pemahaman penyimpangan dan kekerasan seksual yang dianggap tidak layak untuk diberikan kepada anak-anak sekolah dasar. Tujuan penelitian ini adalah untuk menganalisis pengaruh kegiatan bercerita dengan boneka tangan terhadap hasil belajar penyimpangan materi dan kekerasan seksual dalam hal motivasi belajar siswa sekolah dasar.

Penelitian ini dirancang menggunakan pendekatan one group post design dengan analisis uji $\mathrm{T}$ independen dengan taraf signifikansi 0,05. Responden dalam penelitian ini adalah 38 anak usia sekolah 3-4 SD di SD Muhammadiyah 9 Kenjeran Surabaya yang diambil dengan teknik Nonprobabiliti purposive sampling. Teknik pengumpulan data menggunakan (1) tes, digunakan untuk mendapatkan data hasil belajar (2) Kuesioner MSLQ (Motivated Strategic for Learning Questionnaire). digunakan untuk mengumpulkan data tentang motivasi belajar siswa.

Hasil penelitian menunjukkan bahwa nilai rata-rata hasil belajar adalah 65 dan $61 \%$ siswa mencapai hasil belajar yang baik. Hasil belajar siswa adalah pengetahuan siswa tentang bentuk perilaku menyimpang dan kekerasan seksual pada anak-anak dan bagaimana menangani perilaku menyimpang dan kekerasan seksual pada anak-anak. Hasil penelitian juga menunjukkan bahwa tidak ada varian signifikan pada motivasi belajar siswa pada hasil belajar dengan nilai $\mathrm{P}=0,139>0,05$

Kesimpulan dari penelitian ini adalah penggunaan kegiatan story telling dengan boneka tangan dapat menghasilkan pembelajaran yang baik outcame pada materi penyimpangan dan kekerasan seksual pada siswa sekolah dasar dilihat dari setiap tingkat motivasi.
\end{abstract}

Kata kunci: NELIDA Hand Puppet, Penyimpangan dan Kekerasan Seksual, Siswa Sekolah Dasar

\footnotetext{
ABSTRACK

Deviation and sexual violence against children is a frequent phenomenon today. One of the factors that influence the case of deviation and sexual violence in children because of the low understanding of deviations and sexual violence that are considered not feasible to be given to elementary school children. The purpose of this study is to analyze the influence of story telling activities with hand puppet on the learning outcomes on the material deviation and sexual violence in terms of motivation to learn elementary school students.

This research desigend used one group-post test design approach with independent $T$ test analysis with significance level 0,05. The responden in this study were 38 children of 3-4 grade school age at SD Muhammadiyah 9 Kenjeran Surabaya taken with Nonprobabiliti purposive sampling technique. The techniques of collecting data used (1) test, was used to get learning outcame data (2) MSLQ Questionnaire (Motivated Strategic for Learning Questionnaire). was used to collect data about student learning motivation.

The results of research showed that the average value of learning outcomes is 65 and $61 \%$ of students attain good learning outcomes. Students 'learning outcomes are students' knowledge about the form of deviant behavior and sexual violence in children and how to deal with deviant behavior and sexual violence in children. The results also indicate that there is no significant variant on the students' learning motivation on the learning outcomes with $P$ value $=0,139>0,05$

The conclusion of this research is the use of story telling activity by hand puppet can produce good learning outcame on the material deviation and sexual violence in elementary school student in viewed from each level of motivation.
}

Keyword : NELIDA Hand Puppet, Deviation and sexual violence, Elementary School Student 


\section{PENDAHULUAN}

Kasus kekerasan seksual pada anak di dunia menurut data dari National Children's Alliance (NCA) pada tahun 2013 terdapat 202,265 kasus. Tahun 2014 jumlah kekerasan seksual pada anak meningkat menjadi 205,438. Namun terjadi penurunan kasus kekerasan seksual pada anak pada tahun 2015 dari bulan Januari sampai Juni menjadi 101,769 (NCA, 2015). Sementara di Indonesia, menurut Komnas Perlindungan anak, pada semester pertama tahun 2013, terdapat 294 kasus (28\%) kekerasan fisik, 203 kasus (20\%) kekerasan psikis, dan 535 kasus (52\%) adalah kekerasan seksual. Itu berarti setiap bulan terdapat 90 - 100 anak mengalami kekerasan seksual. Bentuk-bentuk kekerasan seksual berupa sodomi (52 kasus), pemerkosaan (280 kasus) dan pencabulan (182 kasus) serta incest (21 kasus) (Anastasia, 2013).

Sekolah Dasar Muhammadiyah 9 Surabaya merupakan salah satu sekolah dasar yang terletak dikawasan surabaya utara. Kawasan surabaya utara membentang dari Kecamatan bulak sampai kecamatan krembangan. Di kawasan tersebut terdapat berbagai wisata pantai, seperti pantai kenjeran, jembatan surabaya serta KENPARK (Kenjeran Park). Potensi wisata tersebut dimanfaatkan oleh masyarakat khususnya kalangan remaja untuk melakukan perbuatan yang tidak layak diperlihatkan oleh khayalak umum khusunya anak-anak dibawah umur, seperti berpegangan tangan dan berpelukan dengan lawan jenis.

Kondisi objektif kawasan tersebut menimbulkan dampak yang buruk bagi anakanak dibawah umur yang melihat perilaku menyimpang dari kalangan remaja. Hal tersebut memunculkan berbagai pertanyaan dan keingintahuan yang tinggi terhadap apa yang mereka ketahui secara langsung. jika tidak ada penanganan yang tepat untuk mengatasi masalah tersebut maka anak-anak akan lebih mudah terpengaruh dan meniru perilaku menyimpang tersebut.

Perilaku menyimpang yang dapat ditimbulkan adalah kekerasan dan penyimpangan seksual pada anak dibawah umur. Kekerasan dan penyimpangan seksual terhadap anak merupakan fenomena yang sering terjadi saat ini. Maraknya kasus kekerasan seksual terhadap anak dipicu karena masih rendahnya pemahaman pendidikan seksual yang dianggap sesuatu yang tabu dan tidak layak untuk diberikan kepada anak dibawah umur.

Akhir-akhir ini marak terjadi kasus kekerasan dan penyimpangan seksual di daerah kenjeran surabaya salah satunya yaitu seorang gadis yang menjadi korban penyekapan, pengancaman dan pelecehan seksual. Peristiwa tersebut terjadi dini hari sekitar pukul 00.15 WIB pada Jumat (26/5/2016). Kasus lain yang terjadi yaitu, kasus pencabulan terhadap M yang dilakukan oleh penjaga sekolah di Kenjeran Surabaya terjadi pada Maret 2015 dan April 2015. (detiknews, 2017)

Hal yang paling mungkin untuk segera kita upayakan adalah usaha-usaha pencegahan (preventif) untuk menekan laju insidensinya dan rehabilitatif untuk menangani akses dari kekerasan seksual yang sudah terjadi. Apalagi jika korbannya adalah anak-anak, maka upaya pencegahan itu memang haruslah sedini mungkin. Pemberian pengetahuan tentang seksualitas mereka sedini mungkin, akan membentuk kemampuan anak dalam menjaga diri dari segala ancaman dan manipulasi orang dewasa terkait tubuhnya. Hal inilah yang disebut sebagai pendidikan seks pada anak.

Metode pembelajaran dalam memberikan pendidikan perlu ditentukan untuk menetapkan langkah dan tujuan yang akan dicapai (Marlinda et al., 2014). Salah satu metode pembelajaran yang dapat digunakan pada anak adalah menggunakan bantuan bercerita. Bercerita adalah kegiatan untuk mendeskripsikan suatu kejadian yang nyata ataupun karangan (Suhartini, 2013). Belajar dengan metode bercerita membuat peserta belajar menerima informasi dengan cara mendengar dan peserta belajar dapat mengartikan apa yang mereka dengar sesuai dengan pemahamannya, mendengar juga akan mengembangkan kemampuan membaca untuk anak, selain itu juga dapat meningkatkan kemampuan sosieal, kemampuan intelektual, kemampuan bahasa, dan kemampuan berkonsentrasi (Jalongo, 2008 dalam Oduolowu, 2014). Belajar dengan bercerita menggunakan boneka juga dapat meningkatkan ketrampilan anak dalam bercerita atau berbahasa lisan (Nur'aini, 2012; Marlinda et al., 2013; Yuanita, 2014). 


\section{METODE}

Luaran akhir dalam program Nelida (Boneka Limbah Cerdas) ini adalah : (1) menghasilkan sebuah alat peraga berupa boneka limbah cerdas yaitu boneka tangan yang digabungkan dalam sebuah pentas teater boneka; (2) Jurnal publikasi ilmiah berISSN atau terakreditasi di bidang pengabdian masyarakat; (3) siswa-siswi SD Muhammadiyah 9 Surabaya mampu memahami serta mengerti pentingnya pendidikan seksual pada anak; (4) Modul pembelajaran untuk para pendidik serta pembinaan kader cilik duta Nelida.

Metode pelakasanaan secara rinci adalah sebagai berikut :

\section{Observasi dan Survei}

Kegiatan observasi dilakukan di SD Muhammadiyah 9 Surabaya dengan melakukan survei dan wawancara kepada siswaa-siswi untuk mengatahui sejauh mana pemahaman siswa-siswi mengenai pendidikan seksual, selain itu dilakukan juga survei dan wawancara kepada para guru untuk mengetahui perilaku yang dialami siswa-siswi dalam masalah seksual. Selanjutnya dilakukan pre test sebelum dilaksanakannya program Nelida untuk mengetahui sejauh mana pemahaman siswasiswi mengenai pendidikan seksual serta mengetahui minat anak pada program Nelida sebagai media pembelajaran.

\section{Perencanaan Program Kegiatan Nelida}

Perencanaan konsep kegiatan Nelida dilakukan dengan melakukan 5 tahapan sebagai berikut :

a. Persiapan dan Rapat program Nelida

Diadakan rapat koordinasi untuk merencanakan kegiatan program Nelida dan menetapkan karakter boneka Nelida yaitu karakter tokoh cerita rakyat indonesia Timun Mas yang dipilih untuk memudahkan siswa-siswi dalam memahami alur cerita serta maksud yang disampaikan. Selain itu diadakan juga pembuatan naskah berupa dialog yang akan digunakan dalam kegiatan program nelida.

b. Pelatihan dan Pemberdayaan Masyarakat Sekitar

Pada tahapan ini dilakukan sosialisasi program Nelida kepada siswasiswi SD Muhammadiyah 9 Surabaya untuk mengenalkan kegiatan yang akan dilakukan. Selanjutnya dilakukan pemberdayaan kepada para guru dalam pembelajaran modul Nelida serta melakukan pembentukan kader cilik duta Nelida dalam rangka keberlanjutan program Nelida.

c. Penerapan dan Pembelajaran Program Nelida

Penerapan dan pembelajaran program Nelida dilakukan kepada siswasiswi SD Muhammadiyah 9 Surabaya kelas 3 dan kelas 4 sebanyak 38 siswasiswi. Kegiatan ini dilakukan dengan melakukan pentas teater boneka menggunakan boneka tangan yang telah disetting dengan panggung boneka dari limbah yang telah dikumpulkan.

Pada pembelajaran program nelida ini dibagi menjadi 4 pertemuan, yang masing-masing pertemuan akan membahas : (1) Perilaku yang boleh dan tidak boleh dilakukan seorang anak didepan umum; (2) perbedaan anatomi tubuh perempuan dan laki-laki secara sederhana; (3) Proses perkembangan tubuh khususnya organ reproduksi; (4) Dukungan dan suasana kondusif anak agar mau berkonsultasi dengan orangtua untuk setiap pertanyaan tentang seksual dan keekrsn seksual.

d. Publikasi dan Realisasi Nelida

Publikasi realisasi kegiatan Nelida, maka dilakukan dengan pemasangan banner dibeberapa area di sekolah, media eletronik (instagram dan Web UMSurabaya), media cetak (majalah dan artikel), serta kampus sebagai pengenalan program Nelida.

e. Evaluasi dan Laporan Akhir

Setelah dilakukan program pembelajaran, dilakukan evaluasi terhadap efektifitas sebagai media pencegahan kekerasan dan penyimpangan seksual pada anak dengan melakukan post test.

HASIL

Kegiatan ini berjalan dengan baik dengan kerjasama tim serta pihak-pihak yang terkait dengan kegiatan ini. adapun hasil program Nelida adalah sebagai berikut;

a. Pihak Kerjasama

Terdiri dari beberapa pihak seperti Dinas Pendidikan Kota Surabaya, IPANI (Ikatan Perawat Anak Indonesia) Jawa Timur, IPKJI (Ikatan Perawat Kesehatan Jiwa 
Indonesia) Jawa Timur, Majelis Dikdsmen PDM Kota Surabaya, dan SD Muhammadiyah 9 Surabaya. b. Rangkaian kegiatan pengabdian kepada masyarakat :

\begin{tabular}{|c|c|c|}
\hline No. & Jenis Kegiatan & Hasil Kegiatan \\
\hline 1. & Sosialisasi Program Nelida & $\begin{array}{l}\text { Melakukan sosialisasi pengenalan program } \\
\text { Boneka Limbah Cerdas (Nelida) kepada siswa- } \\
\text { siswi SD Muhammadiyah } 9 \text { Surabaya dengan } \\
\text { mengenalkan maksud adanya program Nelida } \\
\text { serta mengenalkan karakter dari boneka yang } \\
\text { akan dimainkan }\end{array}$ \\
\hline 2 & $\begin{array}{l}\text { Pemberdayaan masyarakat } \\
\text { sekitar }\end{array}$ & $\begin{array}{lrrr}\text { Melakukan kaderisasi para } & \text { guru } & \text { dalam } \\
\text { pembelajaran modul belajar } & \text { Nelida } & \text { serta } \\
\text { melakukan pembentukan kader cilik duta Nelida }\end{array}$ \\
\hline 3 & $\begin{array}{l}\text { Pembelajaran dengan program } \\
\text { Nelida }\end{array}$ & $\begin{array}{l}\text { Pembelajaran dengan program nelida dilakukan } \\
\text { menggunakan alat peraga boneka tangan dengan } \\
\text { metode bercertita pada panggung Nelida yang } \\
\text { telah disediakan. Pada pembelajaran nelida ini } \\
\text { menghasilkan pembelajaran dengan pembahasan } \\
: \text { a } \\
\text { a. Pembahasan mengenai perilaku yang boleh } \\
\text { dan tidak boleh dilakukan seorang anak } \\
\text { didepan umum } \\
\text { b. Pembahasan mengenai perbedaan anatomi } \\
\text { tubuh perempuan dan laki-laki secara wajar } \\
\text { c. Pembahsan mengenai proses perkembangan } \\
\text { tubuh } \\
\text { d. Pembahsan tentang dukungan dan suasana } \\
\text { kondusif agar anak mau berkonsultasi } \\
\text { dengan orangtua untuk setiap pertanyaan } \\
\text { tentang seksual. }\end{array}$ \\
\hline
\end{tabular}




\section{c. Evaluasi hasil Nelida}

Hasil penelitian menunjukkan bahwa nilai rata-rata hasil belajar adalah 65 dan $61 \%$ siswa mencapai hasil belajar yang baik. Hasil belajar siswa adalah pengetahuan siswa tentang bentuk perilaku menyimpang dan kekerasan seksual pada anak-anak dan bagaimana menangani perilaku menyimpang dan kekerasan seksual pada anak-anak. Hasil penelitian juga menunjukkan bahwa tidak ada varian signifikan pada motivasi belajar siswa pada hasil belajar dengan nilai $\mathrm{P}=0,139>0$, 05 .

\section{PEMBAHASAN}

Berdasarkan data diatas, maka ada perbedaan antara sebelum dengan sesudah pemberian program Nelida. Hal ini dikarenakan pendidikan seksual memiliki tujuan, menurut Information and education Council of the United State (SEICUS) tahun 2006 tujuan pendidikan seksual adalah untuk memabangun landasan tentang kesehatan seksual bagi anak-anak yang nantinya akan tumbuh dewasa. Anak-anak muda juga dapat memahami tentang nilai, sikap dan wawasan tentang seksualitas. Membantu mengembangkan hubungan dan kemampuan interpersonal mereka dalam menyikapi persoalan seksualitas. Mengembangkan tanggung jawab mereka mengenai hubungan seksualitas termasuk berpakian, larangan, dorongan untuk terlibat dalam hubungan seksual lebih awal (SEICUS,2006). The National Child Traumatic Stress Network (NCTSN) menjelaskan bahwa pencegahan kekerasan seksual bagi anak yang terdeteksi atau tidak terdeteksi sebagai korban kekerasan seksual dapat dilakukan dengan mengajarkan tentang keselamatan tubuh yang sehat, serta membangun komunikasi yang terbuka tentang seksualitas (NCTSN, 2009).

Pembelajaran melalui cerita dapat meningkatkan kemampuan menyimak anak seperti yang dikatakan dalam penelitian Pudi et al., (2014), Fatholah et al., (2014) dan Divtahari et al., (2015) Terdapat lima tahap dalam meyimak meurut Taringan (2008) yakni 1) mendengar, 2) memahami, 3) menginterpretasi, 4) mengevaluasi, dan 5) menanggapi. Tahap menanggapi dimana anak dapat menyerap serta menerima informasi yang dikemukakan oleh pencerita sehingga pengetahuan anak dapat meninkat karena salah satu yang mempengaruhi pengetahuan adalah informasi (Mubarak, 2007). Ditambah lagi dengan bantuan alat peraga visual berupa boneka, yang mendorong pendengat untuk berpartisipasi secara aktif, pendengar merasa terlibat di dalam cerita sehingga mereka seolah-olah melihat sendiri peristiwa yang terjadi dalam cerita yang disampaikan (Simanjuntak, 2008). Menurut Kusmayadi et al., (2008) boneka dapat digunakan sebagai media atau alat peraga yang digunakan untuk lebih menarik perhatian pendengar dan membantu pendengar memahami jalannya cerita. Cerita boneka bukan hanya untuk bersenang-senang atau permainan tetapi juga dapat menyediakan dukungan psikologis bagi anak dan dapat digunakan untuk menyampaikan pesan kehidupan sehari-hari (Fisher,2009) seperti pencegahan kekerasan dan penyimpangan seksual dalam program pengabdian kepada masyarakat ini.

Pembelajaran melalui cerita dapat meningkatkan kemampuan menyimak anak seperti yang dikatakan dalam penelitian Pudi et al., (2014), Fatholah et al., (2014) dan Divtahari et al., (2015) Terdapat lima tahap dalam meyimak meurut Taringan (2008) yakni 1) mendengar, 2) memahami, 3) menginterpretasi, 4) mengevaluasi, dan 5) menanggapi. Tahap menanggapi dimana anak dapat menyerap serta menerima informasi yang dikemukakan oleh pencerita sehingga pengetahuan anak dapat meninkat karena salah satu yang mempengaruhi pengetahuan adalah informasi (Mubarak, 2007). Ditambah lagi dengan bantuan alat peraga visual berupa boneka, yang mendorong pendengat untuk berpartisipasi secara aktif, pendengar merasa terlibat di dalam cerita sehingga mereka seolah-olah melihat sendiri peristiwa yang terjadi dalam cerita yang disampaikan (Simanjuntak, 2008). Menurut Kusmayadi et al., (2008) boneka dapat digunakan sebagai media atau alat peraga yang digunakan untuk lebih menarik perhatian pendengar dan membantu pendengar memahami jalannya 
cerita. Cerita boneka bukan hanya untuk bersenang-senang atau permainan tetapi juga dapat menyediakan dukungan psikologis bagi anak dan dapat digunakan untuk menyampaikan pesan kehidupan sehari-hari (Fisher,2009) seperti pencegahan kekerasan dan penyimpangan seksual dalam program pengabdian kepada masyarakat ini.

\section{KESIMPULAN DAN SARAN}

1. Kesimpulan dari penelitian ini adalah penggunaan kegiatan story telling dengan boneka tangan dapat menghasilkan pembelajaran yang baik outcame pada materi penyimpangan dan kekerasan seksual pada siswa sekolah dasar dilihat dari setiap tingkat motivasi.

2. Seluruh kegiatan yang direncanakan dalam kegiatan PKM Pengabdin Masyrakat dapat berjalan dengan baik dan lancar. Hasil pelaksanaan kegiatan sesuai dengan yang direncanakan, tujuan serta target luaran yang telah ditetapkan dapat tercapai dengan baik.

3. Kegiatan yang berlangsung selama 4 hari ini memberikan manfaat yang sangat berharga bagi anak Sekolah dsar SD Muhammadiyah dimana pada pelatihan ini peserta mendapatkan pengetahuan baru dalam upaya pencegahn penyimpangan dan kekerasan seksual.

4. Pembetukan Duta Nelida dapat dijdikan keberlanjutan dari program PKM Pengabdian Masyarakat.

\section{SARAN}

Duta Nelida yang terbentuk mengharapkan keberlanjutan program dengan terus melakukan edukasi keliling di sekolah dasar yang lain di lingkungan Kenjeran

\section{KEPUSTAKAAN}

Anastasia, 2013

detiknews, 2017

Divtahari et al., 2015

Fatholah et al., 2014

Fisher,2009)

Jalongo, 2008

Kusmayadi et al., 2008

Marlinda et al., 2013

Marlinda et al., 2014

Kusmayadi et al., 2008

Mubarak, 2007

Mubarak, 2007

NCTSN, 2009

Nur'aini, 2012

Pudi et al., 2014,

Simanjuntak, 2008

Simanjuntak, 2008

Suhartini, 2013

Taringan, 2008

Yuanita, 2014 


\section{KONTRIBUSI PENULIS}

ERICA AYU DAMAYANTI sebagai Ketua Peneliti menyusun penelitian, mengawasi pengumpulan data, mengelola data, menyusun naskah dan semua penulis berkontribusi secara substansial terhadap revisinya. GITA MARINI memimpin komite pengawasan data, merancang penelitian, memberikan saran statistik dalam desain penelitian, menganalisis data dan interpretasi. ERICA AYU DAMAYANTI sebagai ketua peneliti bertanggung jawab atas makalah ini secara keseluruhan

\section{UCAPAN TERIMAKASIH (ACKNOWLEDGEMENT)}

Artikel ilmiah ini merupakan bagian dari Laporan Program Kreatifitas Mahasiswa Pengabdian Kepada Masyarakat (PKM-M) yang didanai oleh dana Kemenristek DIKTI tahun 2018 melalui program PKM. Sehingga pada kesempatan ini perkenankanlah penulis mengucapkan terima kasih dan penghargaan kepada: 1) Wakil Rektor 1 Bidang Kemahasiswaan Universitas Muhammadiyah Surabaya yang telah menyetujui pendanaan ini; 2) Dekan Fakultas Ilmu Kesehatan Universitas Muhammadiyah Surabaya yang telah memberi persetujuan pengusulan proposal ini; 3) Rekan Dosen sebagai anggota tim dan rekan dosen yang membantu pelaksanaan PKM Pengabdin Masyarakat; 4) Mahasiswa peserta PKM Pengabdian Masyarakat; 5) Seluruh mitra Pengbdian Masyarakat NELIDA yang telah diajk kerjasama; 6) Semua pihak yang tidak dapat kami sebutkan satu persatu yang telah banyak memberikan bantuan baik moril dan materiil untuk terlaksananya kegiatan PKM Pengabdian Masyarakat kali ini. 